\title{
Impact of tourism infrastructure on regional development: the implantation of a Center Parcs resort in northern France
}

\author{
L. PACAUD \\ Les H aras nationaux, 1 boulevard Victor H ugo, 60200 Compiegne, France and Engref, \\ A ubière, France.E-mail: Iudovic.pacaud@haras-nationaux.fr. \\ D. VOLLET
}

Cemagref, U M R M étafort A groParis Tech-Cemagref-Enita-INRA, 24 avenue des Landais, 63170 A ubière, France. E-mail: dominiquevollet@ cemagref.fr.

\section{ANGEON}

A groParis Tech, U M R M étafort A groParis Tech-Cemagref-Enita-INRA, 24 avenue des Landais, 63170 A ubière, France. E-mail: angeon@engref.fr.

\begin{abstract}
This paper assesses the impact of the implantation of a major recreational resort (670 new direct jobs planned) on the local economy of an isolated rural area in northern France. To estimate the induced effects, an original hybrid model combining Keynesian and economic base theory was used to take into account the predominant role of the first wave of spending in the tourism sector. At the local level, this resort has the potential to create between at least 70 and 80 indirect and induced jobs, provided support is lent by synergy in local policymaking (especially in training and habitat).
\end{abstract}

Keywords: rural tourism; recreational amenities; multiplier; economic base theory; local development; France

JEL classification: R12, R53, R58, H 54, C1

Increasing interregional competition makes the implantation of a tourism facility especially desirable because of the strong population influx and local investment it is calculated to bring. The companies that invest in recreational resorts generally emphasize benefits in terms of local employment to justify 
asking local planning policymakers to support their projects. However, in the current state of knowledge, no firm conclusion can be drawn on the relationship between recreational amenities and regional economic development that is valid for all situations. Deller et al (1997) have simply stated that there may be links between amenities and local economic performance. Marcouiller et al (2004) conclude that tourism linked to recreational amenities may be effective as a local development strategy, though firm evidence is lacking.

O ur purpose here is to contribute to the debate with an analysis of the Center Parcs resort in northern France (Aisne), one of Europe's largest current tourism projects in terms of both investment ( $€ 260$ million in a public-private partnership) and hosting capacity (400,000 visitors per year on 80 hectares, with year-round accommodation on site for 4,000 tourists).

According to economic analysis, unlike many small-sized recreational amenities, this project can act as a 'growth engine' by doubling the hosting capacity of the mainly rural and industrial Aisne département. We set out to assess the potential induced effects of this major tourism project on regional development.

We have approached this from three perspectives:

(1) Theoretical, because we have taken a novel approach, using a hybrid multiplier combining Keynesian and economic base theories. This multiplier proved to be well suited to the specific features of the tourism sector in rural areas and to poorly integrated regional economies. In such areas, leakages may be high during the first wave of spending on recreational or tourism amenities through strong intermediate consumption from outside (Slee et al, 1997). Thus, it is important to make an accurate estimate of the direct injection into the local economy. Our mixed multiplier makes it possible to estimate this wealth accurately (estimation of the $m_{1}$ propensity corresponding to the first spending wave by K eynesian theory) and also its diffusion in different ways according to the diversity of the local economic fabric (estimation of the $\mathrm{m}_{2}$ propensity by economic base theory). This multiplier thus combines the qualities of estimation of the K eynesian theory (estimation of the impact of the first wave of strategic spending in the tourism sector) with the flexibility gained by using the base theory for assessing the effects induced in poorly integrated economies (for which the application or transposition of national or regional ratios is ill suited).

(2) Empirical, through a spatialized estimation of the impact on employment. The choice of an economic base theory multiplier to estimate successive spending waves allows an eval uation of the effects on local employment at different geographical levels. We chose two levels, the pays ${ }^{1}$ (local level) where the infrastructure is located (Laonnois) and the département ${ }^{2}$ (Aisne), which initiated the project and is the main public funding partner. ${ }^{3}$

(3) Political, in terms of how it affects public decision making. The two geographical levels were also chosen because they correspond to the levels of implementation of various sectoral policies: planning and local development at pays level and social and employment policies at département level. This last policy area is important because the tourism sector offers many low-skilled jobs and the area studied presents a strong demand for such 
employment. The spatialized job estimates supplied to public policy decision makers have prompted them to support the project and implement relevant policies (Pacaud, 2005).

First, we briefly present the project for the implantation of the Center ParcsAisne resort. Second, we describe how our theoretical framework fits tourism investment in rural areas. Third, and last, we detail the potential induction effects on local employment at the two geographical levels chosen.

\section{The Center Parcs-Aisne resort project}

The Center Parcs-Aisne resort called 'D omaine du lac de l'Ailette' and located between Laon and Reims in the Aisne département, Picardy (northern France), opened in summer 2007 (J uly). Although the Aisne département ranks fourth out of 94 mainland départements for its number of officially listed historical sites, tourism is not strongly developed here (1.5\% of GDP against a national average of $7 \%$ ), and the number of visitors to its main tourist sites has actually fallen in the past ten years. The département evidently suffers from poor appeal, a lack of major attractions and a climate considered unfavourable by French tourists. $\mathrm{N}$ evertheless, these new facilities will be the third French Center Parcs location after N ormandy (1988) and Sologne (1993). Its ideal location midway between Paris and Brussels, both only 2-2.5 hours away, is expected to attract a northern European clientele (Figure 1).

Center Parcs holiday villages cater for short stays in wooded locations with greenery and water and an emphasis on the natural environment (W aller, 2001). In addition, the concept of a holiday village in a rural area with a tropical pool is still today an exclusive feature of the brand. The 840 cottages can accommodate more than 4,000 people on the site, which is open all year round. It is expected to attract some 400,000 visitors annually. Thus, the Center Parcs's facilities double commercial tourist accommodation capacity in the Aisne département. It is also open all day, so is accessible to people not actually staying there. The Center Parcs resort is located alongside a 140 ha lake and a preexisting golf course. It is equipped with a $5,200 \mathrm{~m}^{2}$ area for water games, restaurants covering some $1,000 \mathrm{~m}^{2}$, shops, a conference centre with a 600 -seat auditorium and a sports hall. This project is in response to: a new social demand, arising from the redistribution of free time; new consumer behaviour; the development of local tourism; and the fragmentation of holidays (Arnaud and K ovacshazy, 1998; Bontron and Morel-Brochet, 2002), etc. It represents a real opportunity to meet these new expectations. Such an important recreational resort located close to the large north European market but implanted in a département without a real tourist tradition is, thus, also innovative.

Public authorities and private enterprise have made a joint investment of more than $€ 180$ million. The Pierre \& Vacances Group, specializing in tourist residences and owner of the Center Parcs brand name, has worked in partnership with the General Council of the Aisne département (the owner of the site) under a public service delegation. The Picardy Regional Council ${ }^{4}$ and the European Union have also together contributed one-quarter of the funding. The Center Parcs-Aisne resort has created 670 non-seasonal jobs, including some 300 unskilled or low skilled. 


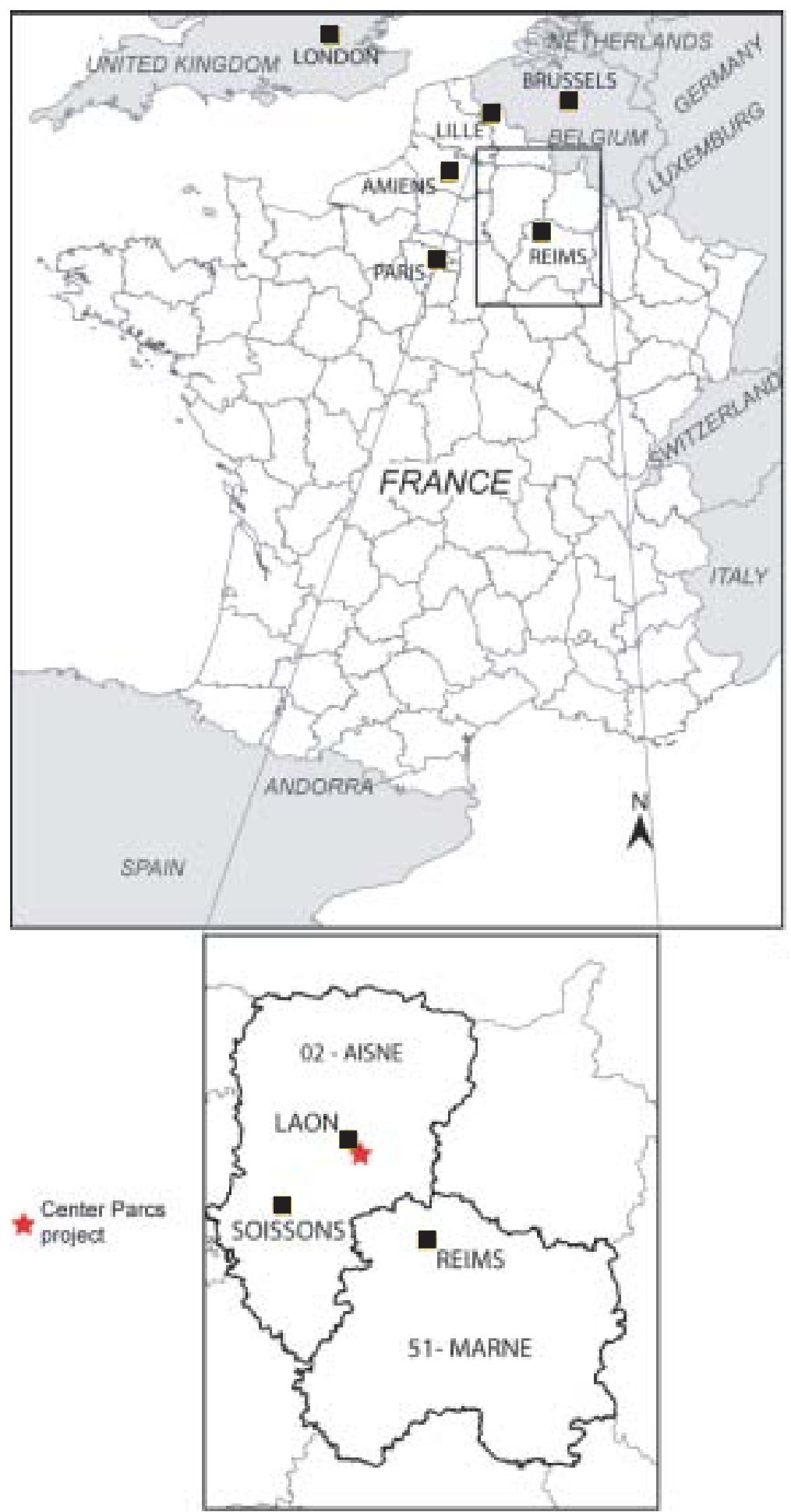

Figure 1. Location of Center Parcs-Aisne resort in Europe. Source: S. Hervio, Équipe économie des espaces ruraux, UMR Métafort, Cemagref. 


\section{An economic analysis suited to tourism investment in rural areas}

Given the flows generated and their expected effects on the local economy, the Center Parcs resort can be considered as a basic driving industry. To measure its impact on a small region, economic base theory is thus appropriate. Our aim was, therefore, to calculate an economic base multiplier.

\section{Recent extensions to economic base theory to allow for tourist activities}

Economic base theory relies on a deliberately simplified dual view of the regional economy in which basic driving activities respond to external demand, while non-basic activities meet local demand. The base multiplier describes how these two types of activity are interrelated. The relations linking the different regional development indicators according to economic base theory are as follows. First, the 'economic base' develops the 'non-base' to a degree that depends on the level of propensity to spend income from the base locally. Combined basic and non-basic expansion then generates wealth and leads to a population increase (MacCann, 2001).

Variations in how activities are assigned to base or non-base have sometimes led to misinterpretation and inappropriate implementation of the theory. The initial formulation of the theory in the 1940s clearly defined the 'economic base' as bringing in income from outside the area. Most of the applications carried out during 1960-80 took as the base those activities that produced goods and services sold outside the area (Richardson, 1985). O wing to the difficulties in obtaining detailed data on the breakdown of regional earnings, the sectors exporting their production out of the study area were identified and considered as the main basic income earners (Isserman, 1980). This type of approximation was empirically acceptable so long as agriculture and industry were the main sources of income in regional economies (Farness, 1989; Mulligan and Kim, 1991; Nelson and Beyers, 1998), ${ }^{5}$ the origin of the demand determining whether the income was basic.

The implementation of base models integrating all export income (including from tourism) illustrates the current relevance of this theoretical framework (H irsch and Summer, 1982; Bain, 1984; Roberts, 2003). 'There is a strong resurgence of base theory in the strict sense [. . . ] there is also a new interest in base theory in its wider sense, which considers all those activities that bring new wealth into the economy' (Dion and Lacour, 2000, p 357). The hostility of a number of contemporary authors to this theory thus derives from a restrictive definition of the base (limited to activities exporting goods or services) (Dion and Vollet, 2001). In these conditions of the application of economic base models, it is difficult, and even impossible, to allow for the deep modifications to rural economies caused by the development of tourism and the influx of commuters, multi-residents and retired people (K rikelas, 1992; K endall and Pigozzi, 1994; Polzin, 2001).

Estimation of the indirect and induced impact of the A isne tourism project: usefulness of a hybrid multiplier combining Keynesian and economic base theories The specific advantages of the chosen multiplier. The multiplier initially devised by Wilson and Raymond (1973), and later refined by a number of other authors 
(Dion, 1987; Rioux and Schofield, 1990), represents a hybrid model combining K eynesian and economic base theories. This model was chosen because it offered the major advantage of differentiating the behaviour of the economic agents studied (here, economic agents involved in tourist infrastructure, students in Dion (1987) and a military base in Rioux and Schofield (1990)) in the first iteration and, subsequently, the whole economy.

In the case of a tourist activity, the leakage of income may be strongly differentiated between the first and subsequent waves because of the high specificities of the tourism actors and the weak integration of the economies concerned. By differentiating several types of base activities, this formulation of the multiplier answers a frequent criticism of the base model, namely that 'the export sector is likely to consist of a number of very different industries with the effect of a change in the exports of these industries having quite different consequences for regional growth and development' (Trendle, 2001, p 356).

In weakly integrated regional economies, the first wave of spending is determining because of the importance of leakages (Sinclair and Sutcliffe, 1984; West and Gamage, 1997). A two-step approach to estimating the propensity to spend locally is thus necessary. The first propensity corresponds to the first spending wave. The second propensity corresponds to the subsequent spending waves, which are of much smaller amplitude (Figure 2).

The multiplier is derived from the following expression, which defines the impact of spending in the local economy as the sum of the extra local income created in successive waves of the multiplier process:

$$
Y=X+m_{1} X+m_{1} m_{2} X+m_{1} m_{2}^{2} X+\ldots+m_{1} m_{2}^{n} X
$$

where $Y$ is the impact on the local economy in income terms (of a category of agents, here those involved in the tourism complex); $X$ is the injection of initial spending counted as income in the local economy; $m_{1}$ is the proportion of $X$ that makes up the local value added in the first spending wave; $m_{2}$ is the propensity to consume locally for the subsequent spending waves.

Equation (1) can be rewritten as follows (Rioux and Schofield, 1990, p 51):

$$
\mathrm{Kr}=\frac{1-\mathrm{m}_{2}+\mathrm{m}_{1}}{1-\mathrm{m}_{1}}
$$

where $m_{1}$ is the propensity of agents to spend locally in the first spending wave (estimated using a K eynesian model); $m_{2}$ is the propensity to spend locally for subsequent spending waves (estimated using economic base theory).

As in the case of previous impact analyses concerning a university (W ilson and Raymond, 1973) and a military base (Rioux and Schofield, 1990), this specification is well suited to analysing the impact of tourist activity in a rural area.

Estimation of the propensity to consume locally in the first spending wave $\left(m_{1}\right)$. We chose to estimate the propensity to spend locally in the first spending wave by a survey using the same procedure as adopted for direct impact.

To estimate the $m_{1}$ propensity, two ratios have to be calculated (W ilson and Raymond, 1973): (i) the percentage of spending related to the tourism infrastructure within the local economy by category (trade, services, etc); and (ii) the 


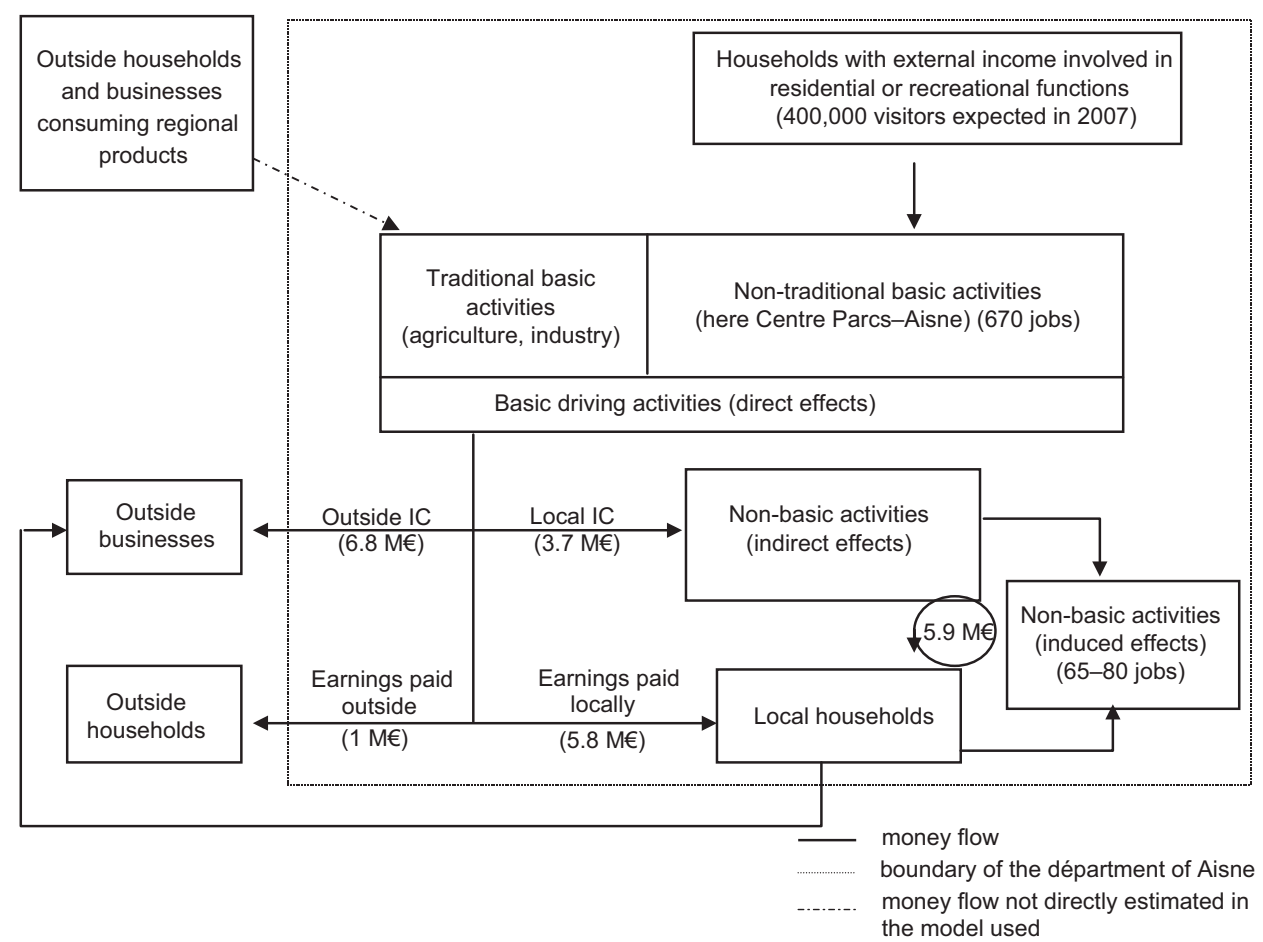

Figure 2. Circulation of money in a regional economy (application to Center Parcs-Aisne resort).

proportion of local value added by category. The earnings-to-sales ratio is generally used as an approximation (Rioux and Schofield, 1990).

If $a_{i j}$ is the percentage of tourism-related spending in the local economy for category i (for example, intermediate consumption) and sector $j$ of activities concerned by this spending (trade, services, etc); $d_{i j}$ is the local spending for spending category $i$ and activity $j ; D_{i}$ is the total spending for category $i ; b_{j}$ is the earnings-to-sales ratio for sector $j ; S_{j}$ is the total salaries in sector $j ; V_{j}$ is the sales in sector $\mathrm{j}$; then:

$$
a_{i j}=d_{i j} / D_{i}
$$

and

$$
b_{j}=S_{j} / V E_{j} .
$$

The estimation of $m_{1}$ is performed for each category of activity involved in the area, by:

$$
m_{1_{i}}=\Sigma j a_{i j} \times b_{j} .
$$

Estimation of the propensity to spend locally in subsequent spending waves $\left(m_{2}\right)$. The second propensity, $m_{2}$, is estimated from economic base theory. This splits regional activities into two components: basic activities supplying external demand and non-basic activities supplying local demand. In terms of jobs, the 
elementary formulation of the propensity to spend locally $\left(m_{2}\right)$ is expressed as follows:

$$
m_{2}=\frac{N \text { on-basic jobs }}{\text { All jobs }} \text {. }
$$

The estimation of basic and non-basic sectors can be performed in different ways (minimum requirements, location quotient, assignment method, etc). ${ }^{6}$ We chose the assignment method as used in a number of recent applications (Mulligan, 1994; Vias and Mulligan, 1995). It offers the double advantage of giving relatively reliable results and of being easy to apply, including at fine geographical scales. We considered the primary and secondary sectors as basic (sectors $E A$ to $E G$ in the French synthetic economic nomenclature (N ES)). Construction and the tertiary sector were considered non-basic.

\section{Probable effects of the Center Parcs resort on local employment}

\section{Effects on local employment arising from intermediate consumption}

Estimation of $m_{1}$. To estimate the possible effects of the Center Parcs-Aisne resort, different estimation ranges are proposed based (i) on figures advanced by the Pierre \& Vacances $G$ roup on planned investments and (ii) on spatialized purchasing behaviour observed at the other French Center Parcs resorts (Sologne and $\mathrm{N}$ ormandy) (Table 1).

(1) Estimation of the total volume of intermediate consumption of Center Parcs-Aisne: the Center Parcs-Sologne complex has $10 \%$ more cottages than the $\mathrm{N}$ ormandy one. This corresponds to a running intermediate consumption level of about 3-4\%. H omothetically, the sum total of the running intermediate consumption of the Center Parcs-Aisne facilities should thus be $9-12 \%$ higher than that of the $\mathrm{N}$ ormandy facilities $(30 \%$ more cottages). ${ }^{7}$ The annual sum total of intermediate consumption of the Center Parcs-Aisne resort, not counting energy (for instance, $D_{i}$, i being the intermediate consumptions: see Equation (3)), will thus amount to about $€ 10.5$ million (inclusive of tax).

(2) Estimation of the 'local' intermediate consumption: at the département level, the proportion of intermediate consumption paid for locally ranges between $27 \%$ (N ormandy resort) and $40 \%$ (Sologne resort). We have taken an average value of $35 \%$. A t the infra-département level, the Pierre \& Vacances Group communicated to us the local ization of its spending on intermediate consumption at the $\mathrm{N}$ ormandy resort, according to a specific breakdown into four zones: one $\left(Z_{0}\right)$ corresponding to the Verneuil-sur-Avre canton (where the resort is implanted), and three $\left(Z_{1}, Z_{2}\right.$ and $\left.Z_{3}\right)$ corresponding respectively to the host département (Eure), the adjoining départements (Calvados, Eure-et-Loir, Orne and Seine-M aritime) outside the Ile-de-France, and the rest of the world. In the centre of N ormandy, $12 \%$ of the spending is inside the canton where the resort is implanted and $15 \%$ is in the rest of the département. 


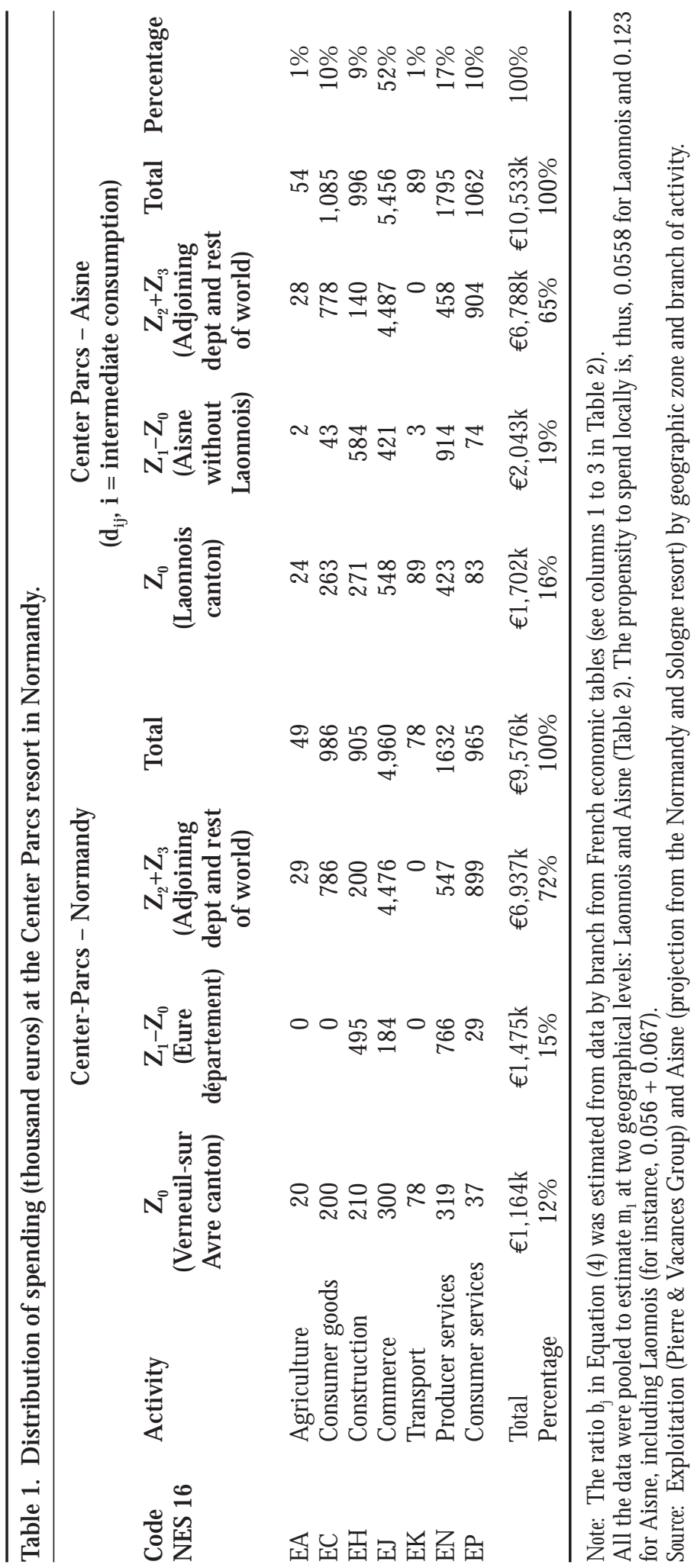




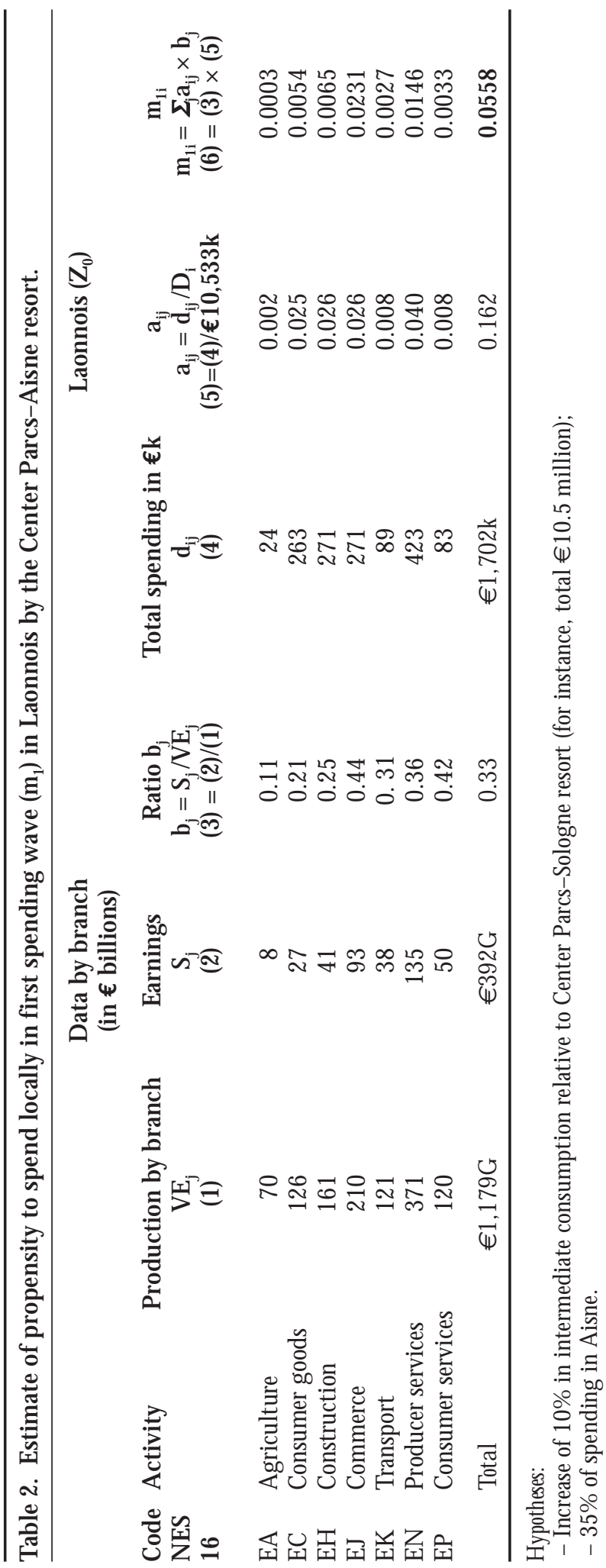


Table 3. Estimate of propensity to spend locally in first spending wave $\left(m_{1}\right)$ in Aisne without Laonnois for the Center Parcs-A isne resort.

A isne (outside Laonnois) $\left(\mathbf{Z}_{1}-\mathbf{Z}_{0}\right)$

Code Activity
NES

16

EA Agriculture

EC Consumer goods

$\mathrm{EH}$ Construction

EJ Commerce

EK Transport

EN Producer services

EP Consumer services

Total

$\begin{array}{cc}\text { Data by } & \text { Total spending } \\ \text { branch ratio } & \text { in } € k \\ b_{j} & d_{i j}\end{array}$

(1)

\subsection{1}

0.21

0.25

0.44

0.31

0.36

0.42

0.33
(2)

(3) $=(2) / € 10,533 \mathrm{k}$ $m_{1 \mathrm{i}}$ $m_{1 \mathrm{i}}=\Sigma_{\mathrm{j}} \mathrm{a}_{\mathrm{ij}} \times \mathrm{b}_{\mathrm{j}}$
(4) $=(3) \times(1)$

H ypotheses:

- Increase of $10 \%$ in intermediate consumption relative to Center Parcs-Sologne resort (for instance, total €10.5 million);

- 35\% of spending in Aisne.

Table 4. Estimate of propensity to spend locally in subsequent spending waves $\left(m_{2}\right)$ for Aisne and Laonnois.

\begin{tabular}{lcccc}
\hline Zone & $\begin{array}{c}\text { Total } \\
\text { employment } \\
\text { (TE) }\end{array}$ & $\begin{array}{c}\text { Basic } \\
\text { employment } \\
\text { (BE) }\end{array}$ & $\begin{array}{c}\text { Non-basic } \\
\text { employment } \\
\text { (N BE) }\end{array}$ & $\begin{array}{c}\text { Propensity } \\
\mathbf{m}_{\mathbf{2}}\end{array}$ \\
& $\mathbf{( 1 )}$ & $\mathbf{( 2 )}$ & $\mathbf{( 3 )}$ & $\mathbf{( 4 ) = ( 3 ) / ( \mathbf { 1 } )}$ \\
Aisne $\left(Z_{1}\right)$ & 180,981 & 128,156 & 52,825 & 0.29 \\
Laonnois $\left(Z_{0}\right)$ & 35,999 & 25,783 & 10,216 & 0.28 \\
\hline
\end{tabular}

Source: 1999 population census.

(3) Breakdown of spending by sector $\mathrm{j}$ : the breakdown of intermediate consumption by sector was carried out at a relatively fine NES level (36), 8 but only for the centre of $\mathrm{N}$ ormandy. We used this breakdown of spending by sector $\left(D_{i j}\right.$ with $i=$ intermediate consumption spending and $j=16$ in NES code) for the estimates made in the centre of the Aisne département. In parallel to the calculations done for $\mathrm{N}$ ormandy by zone, we considered three spatial levels to assess the effects of the tourism project, namely Laonnois $\left(Z_{0}\right)$, Aisne département $\left(Z_{1}\right)$, the adjoining départements outside llede-France $\left(Z_{2}\right)$ and the rest of the world $\left(Z_{3}\right)$ (see Tables 2 and 3 ).

Estimate of $m_{2}$. The propensity to spend locally in the subsequent spending waves $\left(m_{2}\right)$ was estimated by calculating the ratio of non-basic employment to total employment (see Equation (6)). This propensity is slightly lower in Laonnois (0.28) than in the rest of Aisne (0.29) (Table 4). 
Estimate of the multiplier and the effects on employment.

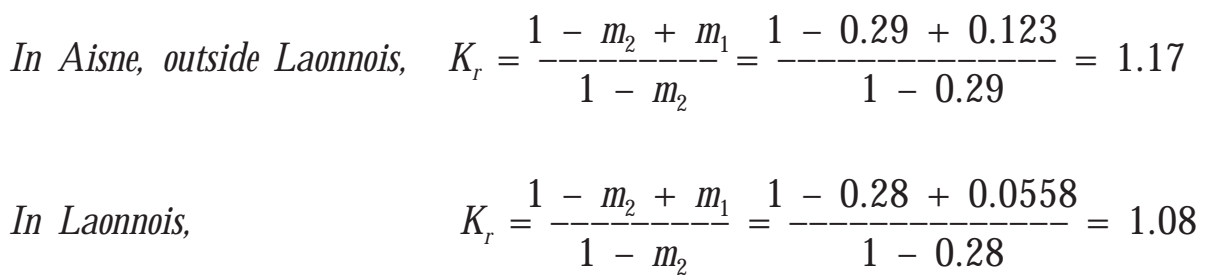

The multiplier effect $\left(K_{r}\right)$ of the Center Parcs-Aisne resort is appreciably lower in Laonnois (1.08) than in the rest of Aisne (1.17) because of the lower level of economic integration of Laonnois (due to a weakly diversified economic fabric). The estimated level of the employment multiplier effects is comparable to that obtained by a similar method in analogous areas. ${ }^{9}$ For example, Guillemette and Thiboutot (1999) obtained a multiplier of 1.04 for the La Baie-Bas-Saguenay region of Quebec (population 28,000). Archer (1982, p 241) found similar values (between 1.08 and 1.47 for tourism income multipliers in villages in Wales) for a number of rural counties in Britain.

To estimate total effects (direct, indirect and induced ${ }^{10}$ ), the intermediate consumption by activity (for instance, direct injection into the local economy) is multiplied by $K_{r}$. This total spending is then converted into jobs using the relevant national accounting ratios (Table 4). It is then possible to give an estimated range for the number of jobs related to intermediate consumption according to the total amount of intermediate consumption estimated by experts (€10 million, that is, only $5 \%$ more than for Center Parcs-Sologne with $€ 11.5$ million, therefore, $20 \%$ more). ${ }^{11}$ The direct, indirect and induced effects on jobs of intermediate consumption of the Centre Parcs-Aisne resort range between 42 and 48 jobs (full-time equivalent: FTE) in the whole département of Aisne and between 19 and 22 jobs in Laonnois (Tables 5 and 6 ; Figure 2). ${ }^{12}$

\section{Employee spending effects on local employment}

Estimates of the effects on local employment of the spending of earnings were made on the basis of two hypotheses advanced from observed job distribution at the Center Parcs-Sologne resort, where $80 \%$ of the employees lived less than 45 minutes away. As the Aisne département was more densely populated than the Loir-et-Cher département, we adopted the experts' estimate that $80-90 \%$ of the employees would probably live less than 40 minutes from the Center Parcs resort ( $H$ ypotheses 1 and 2; Table 7).

According to our estimates, in the Aisne département, for a workforce of 670 , the Center Parcs resort will generate between at least ${ }^{13} 65$ and 80 indirect and induced jobs through intermediate consumption and the successive spending waves of the employees of the tourist resort. In all, the sum of direct, indirect and induced jobs linked to the Center Parcs resort should represent about $0.5 \%$ of total employment in the Aisne département, bringing it cl oser to average levels for jobs in tourism (4\% for France, 3\% for the Aisne). Thus, this major tourist amenity can potentially act as a focus for development. In the model used (the economic base model), labour supply and demand are assumed to be fully elastic. In reality, in particular in the European context, there is much 


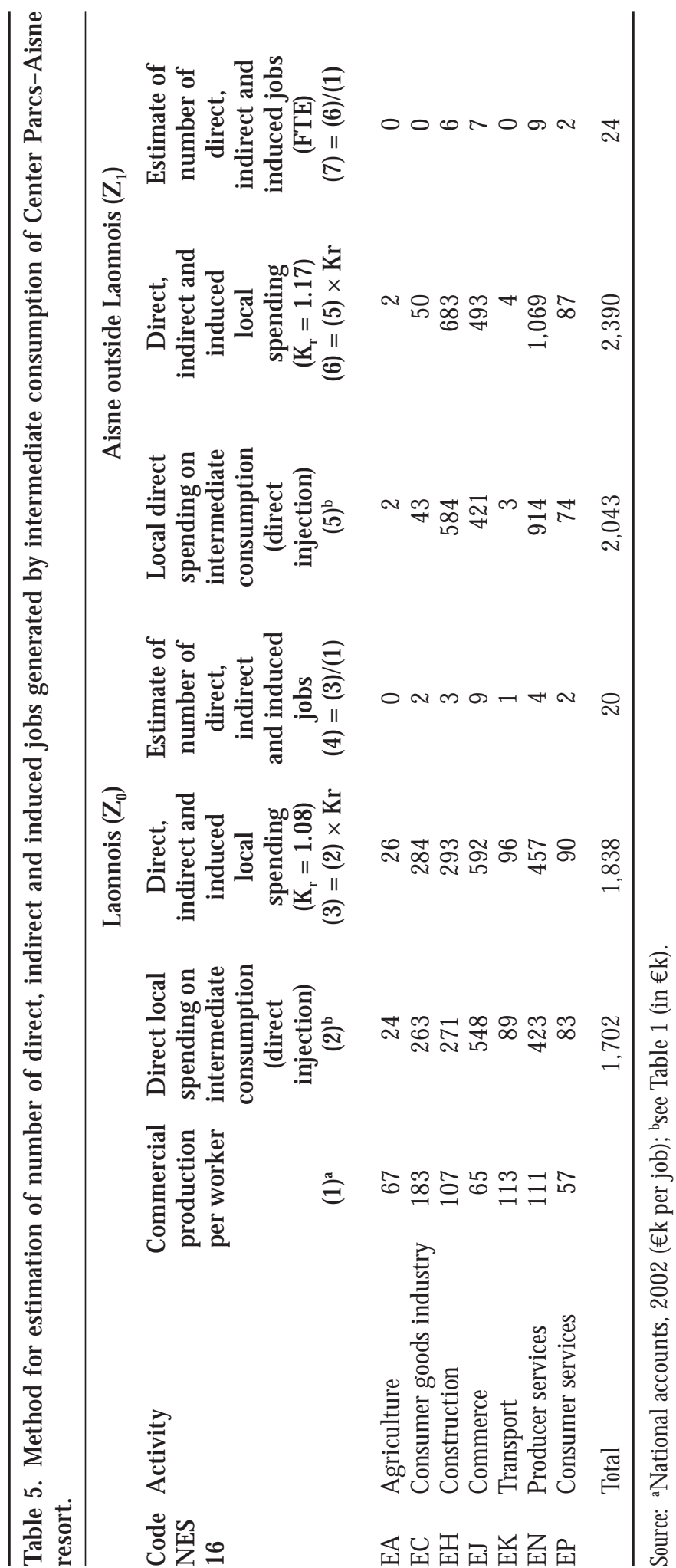


Table 6. Estimated number of indirect and induced jobs arising from intermediate consumption of Center Parcs-Aisne resort.

\begin{tabular}{lcccc} 
Zone & $€ 10 \mathrm{M}(+5 \%)$ & $€ \mathbf{1 0 . 5 M}(+\mathbf{1 0} \%)$ & $€ 11 \mathrm{M}(+\mathbf{1 5 \% )}$ & $€ 11.5 \mathrm{M}(+\mathbf{2 0} \%)$ \\
Aisne $\left(Z_{1}\right)$ & 42 & 44 & 46 & 48 \\
Laonnois $\left(Z_{0}\right)$ & 19 & 20 & 21 & 22 \\
\hline
\end{tabular}

Table 7. Estimated number of indirect and induced jobs arising from spending of employees at Center Parcs-A isne resort.

Hypothesis 1

$\begin{gathered}\text { Aisne } \\ \text { outside }\end{gathered}$
Laonnois $\begin{gathered}\text { Aisne Lonnois } \\ \text { outside } \\ \text { Laonnois }\end{gathered}$

Estimated net total earnings of

employees in €k (1)

$\%$ of net earnings of employees spent

local ly in commerce $\left(a_{i j}\right)(2)^{b}$

$m_{1}(3)=(2) \times$ ratio $b_{j}$ for commerce

(0.44: see Table 3)

$\mathrm{m}_{2}(4)$

$K_{r}(5)=[1-(4)+(3)] /[1-(4)]$

Direct, indirect and induced local effects

(6) $=(1) \times(2) \times(5)$

Estimated number of direct, indirect and

induced jobs $(7)=(6) / 65^{c}$

$\begin{array}{cccc}5,035 & 3,710 & 5,755 & 4,371 \\ 0.28 & 0.25 & 0.28 & 0.25 \\ 0.13 & 0.11 & 0.13 & 0.11 \\ 0.29 & 0.28 & 0.29 & 0.28 \\ 1.18 & 1.15 & 1.18 & 1.15 \\ 1,664 & 1,067 & 1,901 & 1,257 \\ 26 & 16 & 30 & 19\end{array}$

Source: apierre \& Vacances G roup; ${ }^{\mathrm{b}} \mathrm{A}$ isne Chamber of Commerce and Industry; cfigures for production per worker: N ational Accounts, 2002 (€k per job).

inflexibility in the labour market (low mobility, shortage of necessary qualifications, etc). It is, therefore, necessary to consider the conditions in which the Center Parcs resort can actually generate growth. To do this, links between the different sectors (training and construction, in particular) are vitally important to fit the Center Parcs job supply to the available labour, both quantitatively and qual itatively. Spatial ized job estimates are the first step in making policymakers aware of the importance of proactive measures to favour the necessary adjustments.

A place for spatialized estimation of employment in public policymaking

The Center Parcs-Aisne resort will not be able to act as a development engine unless intersectoral meshing (similar to the upstream and downstream linkages of Perrouxian theory) is achieved in training, housing, retailing and other agents involved in tourism (especially agritourism and cultural visits). To accomplish this, concerted public action at different geographical levels is vital to develop skills, build an attractive tourism supply that is consistent and appropriately scaled, improve the circulation of information on job requirements and impel 
a greater involvement of local administration and authorities responsible for habitat and planning.

First of all, Center Parcs needs a large amount of unskilled or low-skilled labour. To find and train that labour, the Regional Council of Picardy (responsiblefor vocational training since its devolution from central government) should act concertedly with the state-run educational institutes, chambers of commerce and industry (for the training of catering apprentices) and the Ministry of Agriculture (for landscape upkeep).

Secondly, the General Council, aware of the importance of the housing issue, has asked an association (A isne $\mathrm{H}$ abitat) to carry out a survey on vacant housing and building land availability. In fact, in both Laonnois and Aisne in general, the comparison of employment estimates and currently available and potential new housing shows that only one fifth of the housing needs can be met. For example, in June 2001 the Laonnois planning authorities approved a construction policy that strongly restricted building in southern Laonnois, where the Center Parcs resort is implanted. The overall opportunities for urban development around the complex thus appear limited and, indeed, unwelcome at a very local level. These restrictions could, therefore, partly jeopardize the local development needed by the workforce employed. A concerted action bringing together all the public urban planning schemes and regulatory provisions operating at all the relevant levels is necessary to optimize this potential.

Thirdly, knock-on effects may also impact on other tourist activities. In this case, there are many opportunities that can be usefully exploited: improved skills, development of host structures (still weak in the area and uneven in quality), thematization of the tourism supply, etc. Such strategies, designed to provide the area with a better devel oped structure for tourism, could thus enable it to make better use of its many attractions.

\section{Conclusion}

An estimate of the spatialized impact on local employment of the implantation of the Center Parcs-Aisne resort is of both theoretical and empirical interest. From a theoretical standpoint, it shows the usefulness of a hybrid multiplier combining Keynesian and economic base theories to assess the effects of new tourist amenities in rural areas. More empirically, it allows spatialized employment estimates to be made that are valuable and have been requested for public policymaking (Leven, 2000). Some 750 direct, indirect and induced jobs can potentially be created in A isne. Supported by these results, our study stimulates thinking on the analysis of the conditions in which the Center Parcs resort can act as a growth engine. Like the steelmaking complexes implanted in southern regions with no industrial background, the implantation of a theme park in a region with an agricultural and industrial tradition and no long-standing tourism activity is in danger of clashing with local expectations. One of the merits of the estimates made is to draw attention to the need to examine the conditions that need to be met to set up provisions for training, habitat management, an integrated tourism supply and a concerted organization of local authorities (communes, groups of communes, pays, département and region). 
Lastly, in the current scientific debate on the role of recreational amenities in rural development, our results confirm those of studies al ready conducted, particularly in N orth America (Sinclair, 1998; Deller et al, 1997). Although top-class recreational installations are potentially able to make a strong positive impact on regional economic development, this does not always happen. It requires efficient public bodies, joint public-private initiatives and an ability to coordinate different sectoral policies at the local level. The recent opening of Center Parcs-Aisne in summer 2007 should help determine whether the minimal conditions can be met to provide the momentum for long-term regional development.

\section{Endnotes}

1. Set up in 1999 by the Voynet act, the pays is an economically, culturally and socially cohesive area that is not necessarily coextensive with an administrative area.

2. M anaging authority for départements (administrative level corresponding to N UTS 3). The département is subdivided into cantons.

3. The département of Aisne is actually the landowner of the project.

4. Managing authority for Regions (administrative division corresponding to NUTS 2).

5. Obviously, agriculture and industry remain, to varying degrees, essential economic engines in many rural areas.

6. For a detailed presentation of economic base theory, see Vollet and Bousset (2002) and Nicols and Mushinski (2003).

7. This estimate was confirmed by the management of the Pierre \& Vacances Group.

8. The French synthetic economic nomenclature (NES), developed in the context of the European U nion, separates activities into different levels $(3,9,36)$, according to the precision required.

9. Income multipliers cannot be compared with employment multipliers because the methods of estimation are very different, particularly in the tourism sector (Archer and Fletcher, 1990; A rcher, 2000).

10. The indirect effects are defined as 'the impact resulting from successive rounds of local business transactions that result from tourist spending' (Slee et al, 1997). The induced effects are 'the impact on incomes and jobs of the spending of income earned as a result of spending by tourists'. Off-site expenditure was not taken into account in our estimate as it was not relevant to the research objective, which was to assess the impact on employment at a local scale, rather than nationally or internationally.

11. We used a single estimate for the proportion of spending in the département, namely $35 \%$, which was validated by Pierre \& Vacances Group experts.

12. Obviously, the employment estimates were not biased by displacement effects because the estimated employment would not have existed without the investment of the tourism centre.

13. We say 'at least' since we have only considered the percentage of net earnings of employees spent in commerce and not in other economic sectors. $\mathrm{N}$ evertheless, this portion of the spend is the major part of the total local spend.

\section{References}

Archer, B., and Fletcher, J. (1990), 'Multiplier analysis in tourism, Aix en Provence: U niversité de D roit, d'Economie et des Sciences, Centre des $\mathrm{H}$ autes Etudes Touristiques', L es $\mathrm{C}$ ahiers du Tourisme, série C, No 103, 58 p.

Archer, B.H . (1982), 'The value of multipliers and their policy implications', Tourism M anagement, Vol 54, pp 236-241.

A rcher, B.H . (2000), 'The value of multipliers and their policy implications', The E conomics of Tourism, Vol 2, pp 3-8.

A rnaud, G., and K ovacshazy, C. (1998), 'Réinventer les vacances, la nouvelle galaxie du tourisme: rapport du groupe d'experts', P rospective de la demande touristique à I'horizon 2010, présidé par J ean Viard, Commissariat général du Plan et Direction du Tourisme, Paris: La documentation française. 
Bain, J.S. (1984), 'Transfer payment impacts on rural retail markets: a regression analysis', Regional Science Perspectives, Vol 14, No 1, pp 3-17.

Bontron, J.C., and M orel-Brochet, A. (2002), 'Tourisme et fonctions récréatives: quelles perspectives pour les espaces ruraux?' in Repenser les campagnes, I'Aube DATAR, Paris, pp 173-193 (collection M onde en cours, série Bibliothèque des territoires).

Deller, S., Marcouiller, D., and Green, G. (1997), 'Recreational housing and local government finance', A nnals of Tourism Research, Vol 24, No 3, pp 687-705.

Dion, Y. (1987), Le multiplicateur régional appliqué à un espace économique de petite dimension, B ordeaux, Thèse de doctorat en économie spatiale, Université de Bordeaux I, $264 \mathrm{p}$.

Dion, Y., and Lacour, C. (2000), 'La revanche du sectoriel et le renouveau de l'espace', Revue Canadienne des sciences régionales, XXIII, No 2, pp 343-364.

Dion, Y., and Vollet, D. (2001), 'Les apports potentiels des modèles de la base économique pour guider la décision publique. Illustration à partir de quel ques exemples français et québécois', R evue d'économie régionale et urbaine, No 2, pp 179-196.

Farness, D.H. (1989), 'D etecting the economic base: new challenges', International Regional Science Review, Vol 12, No 3, pp 319-328.

Guillemette, E., and Thiboutot, C. (1999), 'Les retombées économiques des SADC, étude de cas', $\mathrm{R}$ evue Canadienne des sciences régionales, Vol XXII, No 3, pp 263-276.

Harris, T., Shonkwiler, J.S., and Ebai, G.E. (1999), 'D ynamic non-metropolitan export-base modelling', Revien of Regional Studies, Vol 29, No 2, pp 115-138.

H irsch, T.A., and Summers, G.F. (1982), 'Cash transfers and the export base of small communities', Rural Sociology, Vol 47, No 2, pp 295-316.

Isserman, A.M. (1980), 'Estimating export activity in a regional economy: a theoretical and empirical analysis of alternative methods', International Regional Science Review, Vol 5, No 2, pp 155-184.

K endall, J., and Pigozzi, B.W.M. (1994), 'N on-employment income and the economic base of Michigan counties: $1959-1986$ ', G rowth and Change, Vol 25, pp 51-74.

K rikelas, A.C. (1992), 'W hy regions grow: a review of research on the economic base model', E conomic Review, Vol 77, No 4, pp 16-29.

Leven, C. (2000), 'N et economic base multipliers and public policy', R eview of Regional Studies, Vol 30, No 1, pp 57-60.

MacCann, P. (2001), U rban and Regional Economics, Oxford University Press, N ew York, 286 p.

Marcouiller, D., K im, K., and Deller, S. (2004), 'N atural amenities, tourism and income distribution', A nnals of Tourism Research, Vol 31, No 4, pp 1031-1050.

Mulligan, G.F. (1994), 'M ultiplier effects and structural change: applying economic base analysis to small economics', Review of U rban and Regional Development Studies, No 6, pp 3-21.

Mulligan, G.F., and Kim, H. (1991), 'Sectoral-level employment multipliers in small urban settlements: a comparison of five models', U rban G eography, Vol 12, No 3, pp 240-259.

$\mathrm{N}$ elson, P.B., and Beyers, W.B. (1998), 'Using economic base models to explain trends in rural income', G rowth and Change, Vol 29, No 3, pp 295-318.

$\mathrm{N}$ icols, D., and Mushinski, D. (2003), 'Identifying export industries using parametric density functions', International Regional Science Review, Vol 26, No 1, pp 68-85.

Pacaud, L. (2005), Evaluation des retombées économiques du projet de Center Parcs dans I'A isne, Thèse professionnelle, EN GREF Août 2005, 92 p.

Polzin, P.E. (2001), 'W hy some states grow faster than others: new growth model for state economic policy', G rowth and Change, Vol 32, No 3, pp 413-425.

Richardson, H.W. (1985), 'Input-Output and economic base multiplier: looking backward and forward', Journal of Regional Science, Vol 25, No 4, pp 607-661.

Rioux, J.J.M., and Schofield, J.A. (1990), 'Economic impact of a military base on its surrounding economy: the case of C.F.B. Esquimalt, Victoria, British Columbia', Canadian J ournal of Regional Science, Vol XIII, No 1, pp 47-61.

Roberts, D. (2003), 'The economic base of rural areas: a SAM -based analysis of the Western Isles', Environment and Planning A, Vol 35, pp 95-111.

Sinclair, M., and Sutcliffe, C. (1984), 'K eynesian income multipliers and first and second round effects: an application to tourist expenditures', Oxford Bulletin of Economics and Statistics, Vol 44, pp 321-338.

Sinclair, T. (1998), 'Tourism and economic development: a survey', The J ournal of D evelopment Studies, Vol 34, No 5, pp 1-51.

Slee, B., Farr, H., and Snowdon, P. (1997), 'The economic impact of alternative types of rural tourism', J ournal of A gricultural Economics, Vol 48, No 2, pp 179-192. 
Trendle, B. (2001), 'Formulating an economic base model: an application of time series techniques to far N orth Queensland employment data', A ustralasian J ournal of Regional Studies, Vol 7, No 3, pp 353-370.

Vias, A.C., and Mulligan, G.F. (1995), 'Disaggregating economic base multipliers in small communities', Environment and Planning A, No 29, pp 955-974.

Vollet, D., and Bousset, J.P. (2002), 'Use of meta-analysis for the comparison and transfer of economic base multiplier', Regional Studies, Vol 36, No 5, pp 481-494.

Waller, M. (2001), 'Biodiversity and tourism co-exist in harmony', Corporate Environmental Strategy, Vol 8, No 1, pp 48-54.

W est, G., and Gamage, A. (1997), 'Differential multipliers for tourism in Victoria', Tourism Economics, Vol 3, No 1, pp 57-68.

Wilson, J.H., and Raymond, R. (1973), 'The economic impact of a university upon the local community', The A nnals of Regional Science, Vol VII, No 2, pp 130-142. 